\title{
Physical and sensory characteristics of hindquarter muscles of young Holstein, Brahman and Charbray bulls grown under grazing ${ }^{1}$
}

\author{
Melvin Pagán ${ }^{2}$, Américo Casas ${ }^{2}$ and Danilo Cianzio ${ }^{3}$
}

J. Agric. Univ. P.R. 91(3-4):183-195 (2007)

\begin{abstract}
Twenty-seven bulls (10 Holstein, nine Charbray and eight Brahman) grown under grazing conditions were harvested at 31 to 35 months $(598 \mathrm{~kg})$ to study the effect of breed and muscle upon sensory characteristics of tenderness, juiciness and overall acceptance. Hindquarter samples from the psoas major (PM), semimembranosus (SM), semitendinosus (ST), longissimus dorsi (LD), rectus femoris (RF), gluteus medius (GM), and biceps femoris (BF) muscles were taken after a 24-h aging period. Shear force, sensory panel, and intramuscular fat (IF) analyses were performed. Beef quality characteristics were not significantly affected $(P>0.05)$ by breed, and were considered acceptable in tenderness as determined by Warner-Braztler (WBS) and Texture Analyzer (TA.XT2) shear force, and slightly tender, juicy, and acceptable by sensory evaluation. The seven hindquarter muscles of Brahman bulls had a higher $(P<0.05)$ content of intramuscular fat $(1.2 \%)$ than those of Holstein $(0.8 \%)$ and Charbray $(0.9 \%)$. The PM was the most tender hindquarter muscle by WBS, TA.XT2, and sensory evaluation and the most juicy and acceptable $(P<0.05)$. According to WBS, ST was more tender than SM, LD, and BF ( $\mathrm{P}<0.05)$. At the same time, GM and RF were more tender than LD and BF $(P<0.05)$. Conversely, TA.XT2 determined that SM was similar in tenderness to BF ( $P>0.05)$ but tougher than the other muscles $(P<0.05)$. Strategies to reduce the slaughter age of cattle grown under grazing and a better understanding of the mechanisms associated with the deposition of intramuscular fat might result in a greater palatability of the locally produced beef.
\end{abstract}

Key words: tenderness, intramuscular fat, rotational grazing, beef

\section{RESUMEN}

Características físicas y químicas de músculos del cuarto trasero de toros Holstein, Brahman y Charbray criados a pastoreo

Veintisiete toros (10 Holstein, nueve Charbray y ocho Brahman) criados bajo condiciones de pastoreo se sacrificaron a los 31 a 35 meses de edad $(598 \mathrm{~kg})$ para estudiar el efecto de la raza y el músculo sobre las características sensoriales de terneza, jugosidad y aceptación general. Se obtuvieron

${ }^{1}$ Manuscript submitted to the Editorial Board 13 December 2006.

${ }^{2}$ Associate Researcher, Department of Animal Industry, University of Puerto RicoMayagüez, P.O. Box 9030, Mayagüez, P.R. 00681.

${ }^{3}$ Professor, Department of Animal Industry. 
muestras del cuarto trasero izquierdo de los músculos psoas major (PM), semimembranosus (SM), semitendinosus (ST), longissimus dorsi (LD), rectus femoris (RF), gluteus medius (GM), and biceps femoris (BF) luego de un periodo de $24 \mathrm{~h}$ de almacenamiento a temperaturas de refrigeración. Estas muestras se utilizaron para determinar la cantidad de fuerza necesaria para romper la fibra muscular [Warner-Bratzler, (WBS); analizador de textura computadorizado (TA.XT2)], para un análisis por panel sensorial, y para evaluar el porcentaje de grasa intramuscular (marmoleo). No se observó efecto de raza sobre las características de calidad estudiadas $(P>0.05)$, siendo la carne de res local clasificada como de aceptable terneza por WBS y TA.XT2, y como levemente tierna, jugosa, y aceptable por el panel de evaluación sensorial. Los síete músculos del cuarto trasero izquierdo de los toros Brahman tuvieron mayor $(P<0.05)$ contenido de grasa intramuscular $(1.2 \%)$ que los de los Holsteins $(0.8 \%)$ y Charbray $(0.9 \%)$. El músculo PM fue clasificado como el más tierno por WBS, TA.XT2, y por análisis sensorial, además de ser el más jugoso y aceptable $(P<0.05)$. De acuerdo al WBS, el músculo ST fue más tierno que el SM, LD, y $B F(P<0.05)$, mientras el GM y RF fueron más tiernos que el LD y BF $(P<0.05)$. Por el contrario, el TA.XT2 determinó que el SM y BF fueron similares en terneza $(P>0.05)$, aunque el SM fue más duro que los restantes músculos $(\mathrm{P}<0.05)$. El uso de estrategias para reducir la edad a la matanza de vacunos criados a pastoreo y un mejor entendimiento de los mecanismos asociados a la deposición de grasa intramuscular podrían resultar en mejoras en la palatabilidad del producto local.

Palabras clave: terneza, grasa intramuscular, pastoreo rotacional, carne de res

\section{INTRODUCTION}

In Puerto Rico, beef has been gradually losing market share to competing meats and other protein sources. The same is happening throughout the developed world (Moloney et al., 2001). This decline in consumption reflects consumer concerns about diet, health, food safety, animal welfare and environmental sustainability of beef production. In addition, changing consumer lifestyles and the availability of more conveniently prepared foods have affected the demand for beef products (Moloney et al., 2001). Beef tenderness is closely related to its overall acceptability (Chambers and Bowers, 1993). Tenderness is a complex characteristic determined by intrinsic factors within the muscle, which can be influenced by genetics, age and the environment (Purchas et al., 2002). Such factors can have an effect during the animal's growth, at pre-slaughter, during postharvest management, and during cooking (Harper, 1999; Fergusson et al., 2001). Beef cattle genetic improvement programs have traditionally focused primarily on live animal growth traits. However, as consumers become more concerned with diet-health issues and as the beef industry focuses more on value-based marketing, the emphasis on body composition traits will be more important in the design of breeding programs (Marshall, 1994). In 1990, the National Beef Tenderness survey conducted at Texas A \& M University documented a relatively high incidence of toughness problems in beef cuts at U.S. retail supermarkets, and emphasized the need to improve beef ten- 
derness (Morgan et al., 1991). To compete with other sources of food, the beef industry must cost effectively deliver a good and reliable product. To determine whether it would be profitable for the industry to market beef on the basis of tenderness, consumers must be able to consistently recognize tenderness differences (Wheeler et al., 1994). If consumers could do so, beef cattle breeders would be using resources to produce animals that increase profitability of the beef industry as a whole, by supplying the type of meat demanded by consumers (Marshall, 1994). Most of the beef consumed in Puerto Rico is imported from the continental United States. Therefore, it is imperative to characterize locally produced beef to compare its quality with that of imported beef. This is especially important in places like Puerto Rico where beef comes from young bulls instead of steers. The objective of this study was to compare the physical and quality attributes of the seven hindquarter muscles from young bulls of the three main breeds of cattle used as sources of meat in Puerto Rico under grazing conditions. The data collected will contribute to design strategies to increase the efficiency of the local beef production in order to better compete with imports.

\section{MATERIALS AND METHODS}

Eighty-seven Holstein, Charbray and Zebu (mostly Brahman) bulls were evaluated in two grazing trials between May 1991 and January 1995. The bulls rotationally grazed 12 ha of tropical grass pastures until harvest (598 kg, 33 months of age) as described by Casas et al. (1997a, b). From these groups forty-seven bulls of similar final weight were selected for determining differences in offal components, and carcass traits and composition among breed types (Casas et al., 1997b). After slaughter, carcasses were aged at $5^{\circ} \mathrm{C}$ for $24 \mathrm{~h}$ and the left hindquarter of every carcass was separated into its principal components. Muscle samples were collected from the psoas major (PM), semimembranosus (SM), semitendinosus (ST), longissimus dorsi (LD), rectus femoris (RF), gluteus medius (GM), and biceps femoris (BF) of a total of twenty-seven bulls. The connective tissue and superficial fat were removed and weighed before cutting two steaks from the center part of each muscle. Beefsteaks of approximately $5 \mathrm{~cm}$ width were frozen and stored at $-20^{\circ} \mathrm{C}$ until further evaluation. A thawing period of $24 \mathrm{~h}$ at 5 to $10^{\circ} \mathrm{C}$ was used before sample analysis. One of two sample steaks from each muscle was cooked and evaluated by the sensory panel and used for shear force measurements. The other sample was analyzed for intramuscular fat.

Sensory Panel Evaluation: A sensory panel of twelve persons was organized by using the selection method described by Meilgaard et al. (1991). The sensory panel evaluated the beef samples in terms of ten- 
derness, juiciness and general acceptance using the standard Hedonic Scale (1 to 8), wherein scores 8 and 1 represented the most and least tender, juicy and acceptable meat, respectively. The samples were identified with regard to muscle type, breed and animal. After being thawed, the raw samples were weighed and two 1.27-cm cores were taken from the center and used for shear force determination. The remaining samples were aluminum-foiled and placed in disposable aluminum pans $(203 \mathrm{~mm} \times 95 \mathrm{~mm} \times 63 \mathrm{~mm})$ to be cooked in a conventional dry-heat oven, pre-heated to $163^{\circ} \mathrm{C}$, until reaching an internal temperature of $70^{\circ} \mathrm{C}$. The internal temperature in the center of the steaks was monitored with a Koch thermometer. The center of each cooked steak was reserved for shear force determination and the remainder was cut into square pieces that were randomly given to the panelists for sensory evaluation. The panel members were located in individual booths at room temperature and provided with fresh water and four square chunks of beef to ensure that the samples were properly evaluated.

Shear Force Measurements: Two 1.27-cm cores were taken from the center of each cooked sample and a total of six shear force measurements (three per core) were obtained by using the Warner-Braztler Shear Force (WBS) equipment and the Texture Expert for Windows ${ }^{\circledR}$ $1.0 \mathrm{v}$ package software adapted to a Texture Analyzer (TA.XT2). The tenderness value for each sample used for the statistical analysis was the average of six measurements (kg).

Intramuscular Fat Determination: Intramuscular fat was extracted by using acetone as an organic solvent. The steak samples were homogenized in a blender and were analyzed in duplicate by using the Tecator 1043 Soxtec HT fat extraction system (AOAC, 1980). The percentage of fat was calculated by using the following formula:

$$
\text { FAT } \%=\frac{\text { Glass weight }+ \text { Fat }- \text { Glass weight }}{\text { Sample weight }} \times 100
$$

Statistical Analysis: The experimental design was a split-plot in which the main-plot was represented by the animal (hindquarter) and the split-plot by the muscle (within hindquarter). The data were analyzed by using the MIXED procedure of SAS and the respective means were compared by using the Tukey-Kramer test (SAS, 1988). Preplanned contrasts were made between Bos taurus (Holstein) and Bos indicus (Brahman) animals for the mechanic measurements of tenderness, and sensory tenderness by using the CONTRAST statement of SAS (SAS, 1988). The lineal model was:

$\mathrm{Y} h i j k=\mu+\mathrm{A} h(i)+\mathrm{B} i+\mathrm{M} j+\mathrm{BM} i j+\mathrm{E} h i j k$ where: 
Yhijk $=$ Is the $k$ th observation pertaining to the $h$ th bull within the $i$ th breed and the $j$ th muscle

$\mu=$ overall mean

$\mathrm{A} h(i)=$ random effect of the $h$ th bull within the $i$ th breed

$\mathrm{B} i=$ Effect of the $i$ th breed

$\mathrm{M} j=$ Effect of the $j$ th muscle

$\mathrm{BM} i j=$ interaction between the $i$ th breed and the $j$ th muscle

Ehijk $=$ residual error term

Breed as an independent variable showed significant differences ( $P$ $<0.05$ ) with respect to age and mean percentage of intramuscular fat. Therefore, these two variables (age, \% fat) were incorporated into the model as covariates and an ANCOVA (SAS, 1988) was performed. None of the covariates had significant effects upon the muscle attributes analyzed $(\mathrm{P}>0.05)$; thus, they were excluded from the model. In addition, a simple correlation analysis was conducted using the CORR procedure (SAS, 1998) to estimate the level of association between the dependent variables.

\section{RESULTS AND DISCUSSION}

Table 1 shows means for age, number of permanent incisors, slaughter and carcass weight. Holsteins were older $(\mathrm{P}<0.05)$ than Charbray and Brahman animals ( 34.9 vs. 30.9 and 32.3 months, respectively) and had a higher number of permanent incisors (indirect indicator of age) than the Charbray $(P<0.05)$. Slaughter and hot carcass weights were similar among breeds $(\mathrm{P}>0.05)$, overall means were 598 and $339 \mathrm{~kg}$, respectively.

\section{Breed Effects}

Tenderness. Beef quality characteristics observed were not significantly affected $(\mathrm{P}>0.05)$ by breed, and were considered acceptable in tenderness as determined by mechanical methods (WBS, TA.XT2) (Table 2), agreeing with Shakelford et al. (2001) and Wheeler et al. (2004). Beef cuts were judged slightly tender, juicy, and acceptable by sensory evaluation (Table 2) (Price and Schweigert, 1987; Koch, 1988a; Meilgaard et al., 1991). Data from previous studies suggested that Bos taurus cattle produce more tender beef than Bos indicus (Whipple et al., 1990a, b; Marshall, 1994; Sherbeck et al., 1996). Therefore, specific preplanned comparisons were conducted between Holstein and Brahman breeds for shear force and sensory tenderness. No significant differences were found $(\mathrm{P}>0.05)$ for the contrasts evaluated. Koch et al. (1988b) reported sensory tenderness scores of 5.4 and 5.0 for Hereford 
TABLE 1. - Initial age and number of permanent incisors and slaughter and hot carcass weights of young Holstein, Charbray and Brahman bulls. ${ }^{1}$

\begin{tabular}{lccc}
\hline Characteristic & Holstein & Charbray & Brahman \\
\hline Number of animals & 10 & 9 & 8 \\
Age, months $^{2}$ & $34.9 \mathrm{a} \pm 1.3$ & $30.9 \mathrm{~b} \pm 1.8$ & $32.3 \mathrm{~b} \pm 1.1$ \\
Number of teeth $^{3}$ & $4.0 \mathrm{a} \pm 0.0$ & $3.2 \mathrm{~b} \pm 0.7$ & $3.5 \mathrm{ab} \pm 0.8$ \\
Slaughter weight, $\mathrm{kg}^{\text {Hot carcass weight, kg }}$ & $607.0 \mathrm{a} \pm 34$ & $583.0 \mathrm{a} \pm 39$ & $605.0 \mathrm{a} \pm 44$ \\
& $332.0 \mathrm{a} \pm 22$ & $340.0 \mathrm{a} \pm 19$ & $345.0 \mathrm{a} \pm 28$ \\
\hline
\end{tabular}

${ }^{1}$ Means within a row with the same letter are not different $(P>0.05)$.

2The age of Charbray and Brahman bulls was estimated by using information provided by the farmers.

${ }^{3}$ Permanent incisors.

and Brahman cattle, respectively, all of which is in accordance with the values observed in the present study (Table 2). Previous reports have stated that differences in tenderness between Bos taurus and Bos indicus cattle are more pronounced in Sahiwal than in Brahman cattle (Crouse et al., 1989). Nevertheless, other researchers have indicated that as the proportion of Bos indicus increases in the animal genotype, shear force values increase, marbling and sensory tenderness decrease, and there is a greater inconsistency in tenderness (Crouse et al., 1989; Wheeler et al., 1990). These relationships were not observed under the beef production system in which the present study was conducted.

The majority of the differences in beef tenderness are associated with age, sex, muscle localization, and structure and composition of the muscle connective tissue (Hedrick et al., 1994). Age affects beef tenderness negatively because of an increase in the stability and number of

TABLE 2.-Least square means and standard errors of Warner-Bratzler shear force (WBS), Texiure Analyzer shear force (TA.XT2), sensory panel tenderness (T), juiciness (J), general acceptance (GA), and intramuscular fat (IF) of young Holstein, Charbray and Brahman bulls. ${ }^{1}$

\begin{tabular}{lccc}
\hline Variable & Holstein & Charbray & Brahman \\
\hline WBS, kg & $5.7 \mathrm{a} \pm 1.70$ & $5.7 \mathrm{a} \pm 1.70$ & $5.6 \mathrm{a} \pm 1.90$ \\
TA.XT, kg & $8.8 \mathrm{a} \pm 2.80$ & $9.3 \mathrm{a} \pm 3.00$ & $8.7 \mathrm{a} \pm 2.60$ \\
Panel $^{2}$ & & & \\
J & $5.2 \mathrm{a} \pm 0.84$ & $4.9 \mathrm{a} \pm 0.98$ & $5.0 \mathrm{a} \pm 0.84$ \\
T & $5.2 \mathrm{a} \pm 1.10$ & $5.0 \mathrm{a} \pm 1.10$ & $5.2 \mathrm{a} \pm 1.10$ \\
GA & $5.4 \mathrm{a} \pm 0.90$ & $5.2 \mathrm{a} \pm 0.90$ & $5.4 \mathrm{a} \pm 0.80$ \\
IF, \% & $0.7 \mathrm{a} \pm 1.10$ & $0.8 \mathrm{a} \pm 0.70$ & $1.2 \mathrm{~b} \pm 0.90$ \\
\hline
\end{tabular}

${ }^{1}$ Means within a row with the same letter are not different $(P>0.05)$.

${ }^{2}$ Hedonic Scale (1 to 8 ): 8 = extremely tender, juicy and acceptable meat, and $1=$ extremely tough, dry and unacceptable meat. 
the intra- and inter-collagen covalent linkages associated with older animals. Although neither one of these collagen variables was measured in the present study, analysis of covariance was performed by using age as the covariate (SAS, 1988). No significant covariate effect was found for any of the muscle traits measured $(P>0.05)$.

Intramuscular Fat. On average, the seven muscles from the hindquarters of the Brahman bulls yielded a higher $(\mathrm{P}<0.05)$ percentage of intramuscular fat (1.2) than those of Holsteins (0.7) or Charbray (0.8; Table 1). Contrary to these results, Hedrick et al. (1994) reported that because in cattle grown under grazing the intramuscular fat content tends to be lower, the differences among breeds are notably reduced. Conversely, differences in marbling between Bos taurus and Bos indicus are more pronounced in feedlot cattle (Crouse et al., 1989). Since this study was conducted with intact males grown under tropical grazing conditions, differences in intramuscular fat content were not expected among breeds (Sherbeck et al., 1996; Hedrick et al., 1994). Thus, the reason for the higher percentage of intramuscular fat $(\mathrm{P}<0.05)$ found in Brahman bulls is unclear. Nevertheless, Casas et al. (1997b) reported that grass-fed Zebu bulls had a higher percentage of separable fat $(\mathrm{P}<$ 0.05 ) in the hindquarter than Charbray and Holstein bulls. As expected, the average percentage of intramuscular fat in the three breeds (0.9\%) was much lower than the percentage commonly observed in feedlot steers (4 to 10\%) (Crouse et al., 1989; Hedrick et al., 1994).

Marbling is considered by the beef industry to be of great importance in terms of beef tenderness. The consensus is that a higher marbling score is associated with higher tenderness. Nevertheless, studies have shown that this relationship is weak since intramuscular fat content accounts for only 5 to $10 \%$ of the variation in tenderness (Hedrick et al., 1994; Wheeler and Koohmaraie, 1994). Koch et al. (1988a) reported sensory tenderness values of 5.7 to 6.5 and 6.7 to 7.4 for Bos indicus and Bos taurus, respectively, when the intramuscular fat content increased from traces to modest (USDA Meat Grading System). The average intramuscular fat content $(0.9 \%)$ obtained in the animals from the three breeds evaluated in this study corresponded to the fat percentage associated with a USDA Quality Grade of Select (Hedrick et al., 1994). This is important from a human nutrition standpoint because it means that lean beef, or beef with only traces of intramuscular fat, is obtained from animals grown under grazing. Therefore, it is easily possible to provide consumers with beef that satisfies their demand for low-fat healthy food.

The correlation coefficients between the percentage of intramuscular fat and sensory tenderness and juiciness of the meat were $0.40(\mathrm{P}<$ $0.01)$ and $0.29(\mathrm{P}<0.01)$, respectively (Table 4$)$. Without taking this 
information into consideration, intramuscular fat was included in the model as a covariate, since it was assumed that the significantly higher $(\mathrm{P}<0.05)$ intramuscular fat content in Brahman could have some weight with respect to the lack of differences in sensory tenderness and juiciness found between Bos taurus and Bos indicus in this study. However, no significant effect of intramuscular fat as a covariate was found $(\mathrm{P}<0.05)$.

The coefficient of variation for intramuscular fat was far lower in Brahman bulls (75\%) than in Holsteins (157\%) and somewhat lower than that in Charbray ( $87 \%$ ). Holstein is a Bos taurus breed, of large adult size, specialized in milk production. These characteristics and the fact that these bulls were grass fed could have contributed to a slow and unequal rate of intramuscular fat formation and deposition. Given these conditions, the Holsteins would need a heavier live weight and more age to reach the intramuscular fat levels of the Brahman bulls. This may be indicative of differences among these breeds in the rate of fat formation, which is affected by grazing. The present results are in accordance with the report by Casas et al. (1997b) from a study of the hindquarter muscle composition of animals of these same breeds, a study which indicated lowest total fat content in the Holsteins (5.11\%), highest in Brahman (9.40\%) and intermediate (7.23\%) in Charbray.

Juiciness. Although no significant effect of breed was observed for sensory juiciness in the present study, the scores of 4.9,5.0 and 5.2 for Holstein, Charbray and Brahman bulls, respectively, agree with those in reports by Whipple et al. (1990b), Crouse et al. (1989) and Morgan et al. (1993). Juiciness scores for Hereford $\times$ Angus (Bos taurus) crossbred cattle, and 3/8 and 5/8 Sahiwal (Bos indicus) animals, fluctuated between 5.1 and 5.3 (Whipple et al., 1990b). Scores for various beef cattle breeds reported by Crouse et al. (1989) were 5.2 (Hereford and Angus), 5.0 (Pinzgauer and Brahman), and 4.9 (Sahiwal). Moreover, Morgan et al. (1993) did not find differences in juiciness between the meat of bulls (5.1) and that of steers.

\section{Muscle Effects}

Differences in the mechanical (WBS, TA.XT2) and sensory evaluations of tenderness due to muscle were observed $(\mathrm{P}<0.05)$. The PM was classified as the most tender hindquarter muscle by all three methods. According to WBS values, ST was tenderer than SM, LD, and BF (Table 3); GM and RF were tenderer than LD and BF (Table 3). Different results were obtained by the TA.XT2 method in that SM was similar in tenderness to BF but tougher than the rest of the muscles (Table 3). The literature is consistent indicating that the PM is the tenderest muscle of the beef carcass (McKeith et al., 1985; Morgan et al., 1991; 
TABLE 3.-Least square means of Warner-Bratzler shear force (WBS), Texture Analyzer shear force (TA.XT2), sensory panel tenderness (T), juiciness (J), and general

$\zeta$ acceptance (GA), and intramuscular fat percentage (IF) in the psoas major $(P M)$, gluteus medius (GM), rectus femoris $(R F)$, semimembranosus (SM), longissimus dorsi (LD), biceps femoris (BF) and semitendinosus (ST) muscles. ${ }^{1}$

\begin{tabular}{lccccccc}
\hline Variables & PM & GM & RF & \multicolumn{1}{c}{ SM } & LD & BF & ST \\
\hline WBS, kg & $3.4 \mathrm{a}$ & $5.7 \mathrm{bc}$ & $5.6 \mathrm{bc}$ & $6.3 \mathrm{~cd}$ & $6.7 \mathrm{~d}$ & $6.8 \mathrm{~d}$ & $5.1 \mathrm{~b}$ \\
TA.XT2, kg & $6.1 \mathrm{a}$ & $8.9 \mathrm{~b}$ & $8.4 \mathrm{~b}$ & $11.0 \mathrm{c}$ & $9.0 \mathrm{~b}$ & $10.0 \mathrm{bc}$ & $9.1 \mathrm{~b}$ \\
Panel $^{2}$ & & & & & & & \\
J & $6.4 \mathrm{a}$ & $5.0 \mathrm{~b}$ & $4.9 \mathrm{~b}$ & $4.7 \mathrm{~b}$ & $4.6 \mathrm{~b}$ & $4.5 \mathrm{~b}$ & $4.9 \mathrm{~b}$ \\
T & $7.2 \mathrm{a}$ & $5.1 \mathrm{~b}$ & $4.9 \mathrm{bc}$ & $4.8 \mathrm{bcd}$ & $4.5 \mathrm{~cd}$ & $4.3 \mathrm{~d}$ & $5.2 \mathrm{~b}$ \\
GA & $6.9 \mathrm{a}$ & $5.3 \mathrm{bc}$ & $5.2 \mathrm{bc}$ & $5.1 \mathrm{bcd}$ & $4.9 \mathrm{~cd}$ & $4.7 \mathrm{~d}$ & $5.4 \mathrm{~b}$ \\
IF, \% & $1.9 \mathrm{a}$ & $0.8 \mathrm{~b}$ & $0.9 \mathrm{~b}$ & $0.7 \mathrm{~b}$ & $0.7 \mathrm{~b}$ & $0.8 \mathrm{~b}$ & $0.5 \mathrm{~b}$ \\
\hline
\end{tabular}

${ }^{1}$ Means within a row with the same letter are not different $(\mathrm{P}>0.05)$.

${ }^{2}$ Hedonic Scale (1 to 8): 8 = extremely tender, juicy and acceptable meat, and $1=$ extremely tough, dry and unacceptable meat.

Hedrick et al., 1994; Shakelford et al., 1995). However, the information available for tenderness of the other hindquarter muscles is not consistent. In steers, Shakelford et al. (1995) reported no difference $(P>0.05)$ in mechanical tenderness among the muscles LD, ST, GM, BF and SM. Similar results were observed by McKeith et al. (1985) for the LD, GM, $\mathrm{ST}, \mathrm{RF}$, and $\mathrm{SM}$ muscles $(\mathrm{P}>0.05)$; however, $\mathrm{BF}$ was found to be tougher than the others $(P<0.05)$.

No significant differences were observed in sensory tenderness among ST, GM, RF, and SM. The LD was less tender than ST and GM, and of tenderness similar to that of SM and BF (Table 3). These results are in accordance with tenderness as evaluated by mechanical methods, in particular with the WBS, by which the LD and BF were classified as tough muscles in the Holstein, Charbray and Brahman hindquarters (Table 3). The overall correlation coefficient between WBS and sensory tenderness was -0.70 (Table 4), all of which is in agreement with reports from Marshall (1994) and Shakelford et al. (1995). In contrast, a more sophisticated method to determine mechanical tenderness, as is TA.XT2, gave a lower correlation with sensory tenderness $(\mathrm{r}=-0.53$; Table 4$)$. It is possible that WBS and other methods, such as TA.XT2 and the Instron Universal Testing Machine, do not evaluate the same muscle components as suggested by Shakelford et al. (1995), all of which may lead to inconsistencies in tenderness profiles observed among muscles.

The $\mathrm{LD}$ is the muscle commonly used in beef quality studies because of its high economic value and easiness of sampling. McKeith et al. (1985) reported the following ranking for sensory tenderness: PM $>L D$ 
TABLE 4.-Simple correlation coefficients between Warner-Bratzler shear force (WBS), Texture Analyzer shear force (TA.XT2), sensory panel tenderness (T), juiciness $(J)$, general acceptance $(G A)$, and intramuscular fat percentage (IF).

\begin{tabular}{lccccc}
\hline Variable & TA.XT2 & T & J & GA & IF \\
\hline WBS & $0.64^{* *}$ & $-0.70^{* *}$ & $-0.60^{* *}$ & $-0.67^{* *}$ & $-0.28^{* * *}$ \\
TA.XT2 & & $-0.53^{* *}$ & $-0.52^{* *}$ & $-0.49^{* *}$ & $-0.25^{* * *}$ \\
T & & & $0.90^{* * *}$ & $0.95^{* * *}$ & $0.40^{* *}$ \\
J & & & & $0.87^{* * *}$ & $0.29^{* * *}$ \\
GA & & & & & $0.36^{* * *}$ \\
\hline
\end{tabular}

*** $\mathrm{P}<0.01$

$>\mathrm{RF}=\mathrm{GM}$, ST, SM and BF, whereas according to Shakelford et al. (1995) the order was PM $>$ LD $>$ ST $=$ GM $>$ BF $=$ SM. Meanwhile, Burson and Hunt (1986) reported similar sensory tenderness scores for LD and BF. Shorthose and Harris (1990) classified LD as very tender whereas other researchers found this muscle to be of intermediate tenderness (Cross et al., 1984) or even tough (Cristensen et al., 1991). In the present study, LD was one of the less tender muscles of the bovine carcass, as established by both mechanical and sensory methods (Table 3). In general, the sensory tenderness scores for different muscles vary with the exception of the PM and infraspinatus muscles, which are consistently the most tender and desirable muscles in the carcass (McKeith et al., 1985; Morgan et al., 1991; Hedrick et al., 1994; Shakelford et al., 1995), whereas the BF (Mc Keith et al., 1985; Shakelford et al., 1995) is consistently one of the less desirable muscles. This finding is in accordance with the results of the present investigation in which the PM was the tenderest, juiciest and most acceptable muscle (Table 3).

Shakelford et al. (1991) concluded that LD shear force at 1 or $2 \mathrm{~d}$ postmortem is a useful predictor of beef longissimus tenderness after cooler aging (14 d postmortem) with a relatively high degree of accuracy. In that experiment carcasses were classified as tender, intermediate or tough if their longissimus shear value at 1 or $2 \mathrm{~d}$ postmortem was $<6 \mathrm{~kg}, 6$ to $9 \mathrm{~kg}$, or $>9 \mathrm{~kg}$, respectively. Accordingly, the beef produced by the animals processed in the present study was intermediate in tenderness (Table 3). Wheeler et al. (2004), in an effort to determine the accuracy and repeatability of untrained consumer panelists in detecting differences in beef longissimus tenderness, classified strip loins (longissimus lumborum) as tender if mean slice shear forces were $<15 \mathrm{~kg}$, intermediate between 15 and $27 \mathrm{~kg}$, or tough if $>27 \mathrm{~kg}$. By contrast, Miller et al. (2001) conducted a national consumer evaluation for beef tenderness in USDA Select strip loin steaks of known WBS, which they classified as tough if shear force was $>5.7 \mathrm{~kg}$ and tender if 
it was $<3.0 \mathrm{~kg}$. Wulf et al. (1996) designated WBS values of $>3.85 \mathrm{~kg}$ as unacceptable tenderness, whereas Tatum et al. (1999) used WBS values of $>4.54 \mathrm{~kg}$ as the limit to define unacceptable tenderness on the basis of the consensus established at the National Beef Tenderness Conference (NCBA, 1994). In the present study, WBS $>5.0 \mathrm{~kg}$ was equivalent to sensory evaluation tenderness scores of $\geq 5.0$ in all the breeds evaluated ( $5=$ slightly tender). However, the shear force values for $\mathrm{LD}(\mathrm{WBS}=6.7 \mathrm{~kg}$; TA.XT2 $=9.0 \mathrm{~kg}$ ) corresponded to a sensory tenderness classification of slightly tough. Even though this value may not be problematic for the average Puerto Rican consumer, still the WBS measured in young bulls indicates that there is room for improvements in the tenderness of the beef produced in Puerto Rico. Improving tenderness of the locally produced beef is imperative in order to make it more competitive with importations. However, the development of an effective carcass grading system is needed to facilitate commercialization of the product and serve as a guide to consumers.

Beef production practices commonly followed in Puerto Rico result in the slaughter of intact (not castrated) bulls raised on tropical grasses at an average age of 33 months. Under such conditions, Holstein, Charbray and Brahman bulls tend to produce beef relatively tough and slightly juicy and with $1 \%$ or less of intramuscular fat. Management practices that increase the rate of body weight gain could reduce the slaughtering age, which in turn should improve the sensory characteristics, particularly tenderness of the local beef, thus allowing it to better compete with imported beef and increase its sales in the local market.

\section{LITERATURE CITED}

AOAC, 1980. Official Methods of Analysis (13 ${ }^{\text {th }}$ ed.). Association of Official Analytical Chemist, Washington, DC. p. 1298.

Burson, D. E. and M. C. Hunt, 1986. Proportion of collagen types I and III in four bovine muscles differing in tenderness. J. Food Sci. 51:51

Casas, A., M. Antoni, R. Ramos, D. Cianzio and E. Marrero, 1997a. Comparison of Holstein, Charbray, and Zebu bulls for beef production under rotational grazing. I. Grazing performance and economic evaluation. J. Agric. Univ. P.R. 81:101-113.

Casas, A., D. Cianzio and A. Rivera, 1997b. Comparison of Holstein, Charbray, and Zebu bulls for beef production under rotational grazing. II. Offal components and carcass composition. J. Agric. Univ. P.R. 81:115-124.

Chambers, E., IV and J. R. Bowers, 1993. Consumer perception of sensory qualities in muscle foods. Food Technol. 47:116-120.

Christensen, K. L., D. D. Johnson, R. L. West, T. T. Marshall and D. D. Hargrove, 1991. The effects of breed of sire and age at feeding on muscle tenderness in the beef chuck. J. Anim. Sci. 69: 3673.

Cross, H. R., J. D. Crouse and M. D. MacNeil, 1984. Influence of breed, sex, age, and electrical stimulation on carcass and palatability traits of three bovine muscles. J. Anim. Sci. 58:1358. 
Crouse, J. D., L. V. Cundiff, R. M. Koch, M. Koohmaraie and S. C. Seideman, 1989. Comparisons of Bos indicus and Bos taurus inheritance for carcass beef characteristics and meat palatability. J. Anim. Sci. 67:2661.

Ferguson, D. M., H. L. Bruce, J. M. Thompson, A. F. Egan, D. Perry and W. R. Shorthose, 2001. Factors affecting beef palatability farmgate to chilled carcass. Aust. J. Exp. Agric, 41:879-891.

Harper, G. S., 1999. Trends in skeletal muscle biology and the understanding of toughness in beef. Aust. J. Agric. Res. 50:1105-1129.

Hedrick, H. B., E. D. Aberle, J. C. Forrest, M. D. Judge and R. A. Merkel, 1994. Principles of Meat Science. $3^{\text {rd }}$ ed. Kendall Hunt Publishing Company, Dubuque, IA. p. 354.

Koch, R. M., J. D. Crouse, M. E. Dikeman, L. V. Cundiff and K. E. Gregory, 1988a. Effect of marbling on sensory tenderness in "Bos taurus" and "Bos indicus" crosses. J. Anim. Sci. 66 (Suppl. 1):305.

Koch, R. M., J. D. Coruse and S. C. Seideman, 1988b. Bison, Hereford, and Brahman growth and carcass characteristics. In: Beef Research Progress Rep. No 3. p 26. R.L.H. U.S. Meat Animal Research Renter, USDA, ARS, Clay Center, NE.

Marshall, D. M., 1994. Breed differences and genetic parameters for body composition traits in beef cattle. J. Anim. Sci. 72:2745-2755.

Miller, M. F., M. A. Carr, C. B. Ramsey, K. L. Crockett and L. C. Hoover, 2001. Consumer thresholds for establishing the value of beef tenderness. J. Anim. Sci. 79:3062-3068.

McKeith, F. K., D. L. DeVol, R. S. Miles, P. J. Bechtel and T. R. Carr, 1985. Chemical and sensory properties of thirteen major beef muscles. J. Food Sci. 50:869.

Meilgaard, M., G. V. Civille and B. T. Carr, 1991. Sensory Evaluation Techniques, $2^{\text {nd }}$ ed. CRC Press, Boca Raton, FL. pp. 23-36, 201-226.

Moloney, A. P., M. T. Mooney, J. P. Kerry and D. J. Troy, 2001. Producing tender and flavoursome beef with enhanced characteristics. Proc. Nutri. Soc. 60: 221-229.

Morgan, J. B., J. W. Savell, D. S. Hale, R. K. Miller, D. B. Griffin, H. R. Cross and S. D. Shakelford, 1991. National beef tenderness survey. J. Anim. Sci. 69:3274.

Morgan, J. B., T. L. Wheeler, M. Koohmaraie, J. W. Savell and J. D. Crouse, 1993. Meat tenderness and the calpain proteolytic system in longissimus muscle of young bulls and steers. J. Anim. Sci. 71:1471.

NCBA, 1994. National beef tenderness conference executive summary. National Cattlemen's Beef Association, Englewood, CA.

Price, J. F. and B. S. Schweigert, 1987. The Science of Meat and Meat Products, $3^{\text {rd }}$ ed. Food and Nutrition Press, Westport, CT. p. 639.

Purchas, R. W., D. L. Burnham and S. T. Morris, 2002. Effects of growth potential and growth path on tenderness of beef longissimus muscle from bulls and steers. J. Anim. Sci. 80:3211-3221.

SAS, 1988. SAS User's Guide (release 6.03). SAS Inst., Inc., Cary, NC. p. 250.

Shakelford, S. D., M. Koohmaraie, M. F. Miller, J. D. Crouse and J. O. Reagan, 1991. An evaluation of tenderness of the longissimus muscle of Angus by Hereford versus Brahman crossbred heifers. J. Anim. Sci. 69:171.

Shakelford, S. D., T. L. Wheeler and M. Koohmaraie, 1995. Relationship between shear force and trained sensory panel tenderness ratings of 10 major muscles from Bos indicus and Bos taurus cattle. J. Anim. Sci. 73:3333.

Shakelford, S. D., T. L. Wheeler, M. K. Meade, J. O. Reagan, B. L. Byrnes and M. Koohmaraie, 2001. Consumer impressions of tender select beef. J. Anim. Sci. 79:2605-2614.

Sherbeck, J. A., J. D. Tatum, T. G. Field, J. B. Morgan and G. C. Smith, 1996. Effect of phenotypic expression of Brahman breeding on marbling and tenderness traits. J. Anim. Sci. 74:304. 
Shorthose, W. R. and P. V. Harris, 1990. Effect of animal age on the tenderness of selected beef muscles. J. Food Sci. 55:1.

Tatum, J. D., K. E. Belk, M. H. George and G. C. Smith, 1999. Identification of quality management practices to reduce the incidence of retail beef tenderness problems: Development and evaluation of prototype quality system to produce tender beef. J. Anim. Sci. 77:2112-2118.

Wheeler, T. L., J. W. Savell, H. R. Cross, D. K. Lunt and S. B. Smith, 1990. Mechanisms associated with the variation in tenderness of meat from Brahman and Hereford cattle. eJ. Anim. Sci. 68: 4206.

Wheeler, T. L. and M. Koohmaraie, 1994. Prerigor and postrigor changes in tenderness of ovine longissimus muscle. J. Anim. Sci. 72: 1232.

Wheeler, T. L., S. D. Shakelford and M. Koohmaraie, 2004. The accuracy and repeatability of untrained laboratory consumer panelist in detecting differences in beef longissimus tenderness. J. Anim. Sci. 82:557-562.

Whipple, G., M. Koohmaraie, M. E. Dikeman, J. D. Crouse, M. C. Hunt and R. D. Klemm, 1990a. Evaluation of attributes that affect longissimus muscle tenderness in Bos taurus and Bos indicus cattle. J. Anim. Sci. 68:2716.

Whipple, G., M. Koohmaraie, M. E. Dikeman and J. D. Crouse, 1990b. Predicting beef longissimus tenderness from various biochemical and histological muscle traits. J. Anim. Sci. 69:4193.

Wulf, D. M., J. D. Tatum, R. D. Green, J. B. Morgan, B. L. Golden and G. C. Smith, 1996. Genetic influences on beef longissimus palatability in Charolais- and limousinesired steers and heifers. J. Anim. Sci. 74:2394-2405. 